\title{
ПРОБЛЕМА ЕМПАТІЇ В ПСИХОЛОГІЇ ТА ЇЇ ВАЖЛИВІСТЬ У ПРОФЕСІЙНОМУ СТАНОВЛЕННІ ПСИХОЛОГА
}

УДК: 159.923 .2

\section{Чаплак Ян Васильович}

Кандидат психологічних наук, доиент, доиент кафедри психології Чернівеиького національного університету імені Юрія Федьковича, м. Чернівйі (Україна)

\begin{abstract}
Анотація. Стаття пов'язана з аналізом феномену емпатії як складного комплексного психічного явища, суть якого - у співчутті та співпереживанні іншій людині на основі сприйняття ї̈ внутрішнього стану, вміння поставити себе на місце людини, яка страждає, і поглянути на ситуацію ї̈ очима, зрозуміти ї̈ думки та переживання.

Зазначено, що у психологї вивчені поняття, види, форми та механізми емпатії, визначена ї̈ структура та роль у формуванні допомагаючої поведінки та життєдіяльності людини в иілому, проте у дослідженні ицього феномену досі багато невизначеного та спірного.

Мета роботи - теоретично проаналізувати різні аспекти розуміння емпатії в психологї̈ та емпірично дослідити рівень емпатійності майбутніх психологів та ї̈ зв 'язок з їх особистісними характеристиками.

Результати емпіричного дослідження свідчать, щзо, не зважаючи на те, щзо емпатія $є$ професійно цінною якістю психолога, ї розвиток у студентів - майбутніх психологів $\epsilon$ недостатнім. Виключенням є емочійна складова емпатії, яка у більшості досліджуваних проявлясться на високому рівні, кореляційно пов'язуючись із тривожністю та інтернальним рівнем суб' єктивного контролю особистості.
\end{abstract}

Ключові слова: емпатія, співчуття, співпереживання, механізми емпатії, тривожність, інтернальність.

Постановка проблеми і актуальність дослідження. На думку Д. Лабіра, «більшість психологічних проблем, з якими сьогодні стикається людство, виникають через синдром дефіциту емпатії» [9], від якого ми можемо загинути. Це, вочевидь, є віддзеркаленням упевненості Е. Фромма про все більше поширення ринкової орієнтації характеру в соціумі, що зумовлює втрату людиною своєї самоцінності, своєрідності й індивідуальності та сприйняття іiі як товару, домінування егоїстичності та споживацького ставлення до інших, 
що, в свою чергу, відкриває шлях до маніпуляції їх свідомістю. Усе сказане повертає нас до необхідності не лише цінувати, але й вивчати (аналізувати) емпатію як складний психічний феномен, у дослідженні якого досі багато невизначеності, неоднозначних, спірних моментів та лакун; особливо зважаючи на те, що здатність до емпатії можна вважати професійно важливою якістю не лише психологів, але й представників інших «допомагаючих» професій.

Аналіз досліджень і публікацій. До аналізу проблеми емпатії та різних iï аспектів зверталися багато вчених, зокрема, суттєвий внесок у ऑï розробку внесли К. Роджерс, В. А. Петровський, Т. П. Гаврилова, Д. Бетсон, М. Хоффман, Г. Баррет-Ленард, В. В. Бойко, I. М. Юсупов, А. Меграбіан, Н. I. Сарджвеладзе, Т. І. Пашукова, О. А. Троїцька, Л. П. Журавльова, А. Зимянський, О. Д. Кайріс, О. Кормило, Ю. В. Майєр, Т. А. Рябовол, Л. В. Спіцина, Т. Д. Карягина та багато ін., проте й до сьогодні вона не втрачає своєї актуальності.

Поняття «емпатія» бере свій початок ще $з$ давньогрецької філософії, де його розуміли як симпатію і як духовну спільність, завдяки якій люди співчувають один одному. Поняття «емпатія» в давньогрецькій філософії було тотожне за смислом таким поняттям, як «співпереживання» і «співчуття». Перша частина слова «спів-» підкреслює деяку співзвучність, схожість між переживаннями одного суб’ єкта й особистістю «Іншого» [10].

Т.М. Матюх виявлено, що для розвитку, становлення та тлумачення поняття емпатії важливий внесок мають дослідження, пов'язані з поняттями «симпатія», «розуміння» та «вчування» («почування всередину»). Для такої симпатії індивіду необхідно перейти на позицію «Іншого», уявити себе на його місці, в його ситуації $[10$, с. 8$]$.

Отже, розуміння емпатії у сучасному контексті спочатку існувало у філософських розробках, де воно позначалося словом «симпатія» (оскільки поняття «емпатія» ще не існувало) і пов'язувалося з розвитком моральності особистості. Так, Т.П. Гаврилова, проаналізувавши роботи філософів 19 ст., зазначає, що «симпатія» розумілася ними як властивість людської душі і розглядалася як регулятор взаємостосунків між людьми у суспільстві, основа совісті, альтруїзму, справедливості. На думку вченої, в зарубіжній психології найпоширенішим у когнітивному аспекті $\epsilon$ розуміння емпатії як перцептивного акту, що характеризує здатність особистості оцінювати почуття та думки іншої людини в уявлюваному плані, або як соціальний інсайт, комунікацію у внутрішньому плані [7, с.107].

Поняття «емпатія» у психологію було введене Е. Тітченером як аналог німецького Einfühlung, використовуваного до цього Т. Ліппсом, і тлумачилося близько до співзвучного поняття - «симпатія». Т.Ліппс вважав, що, пізнаючи, людина намагається емоційно 
відчути об'єкт, що пізнається, а сприймаючи його, виявляє дещо спільне із собою, і об'єкт розкриває людині свою суть [13].

Мета цієї статті - теоретично проаналізувати різні аспекти розуміння емпатії в психології та емпірично дослідити рівень емпатійності майбутніх психологів та ії зв'язок з їх особистісними характеристиками.

Виклад основного матеріалу. Проаналізувавши історію феномену емпатії у філософiï, В. Ю. Пузиревський приходить до основного висновку, що емпатія, будучи предметом спеціального чи імпліцитного (коли вона позначалася іншими поняттями) аналізу, розумілася філософами як «здатність /спосіб, що забезпечує збереження /відновлення «гносеологічної» дистанції між суб'єктом і об'єктом (суб'єктом) пізнання і спілкування», що початково дана, або «рефлексивно набувається» [14]; що, з точки зору психології емпатії, лише другорядна іï якість, яка не вичерпує суть і роль емпатії у міжособистісному спілкуванні та взаєморозумінні людей. Більш того, таке розуміння емпатії у філософії (згідно В. Ю. Пузиревського) насправді позбавляє іiі не лише психологічного, але й етикоаксіологічного змісту, який, поряд з онтологічним, гносеологічним і методологічним, згаданими науковцем, постулюються філософі$\epsilon ю$.

Зазначимо, що можна погодитися 3 В. Ю. Пузиревським, що процес емпатії починається з глибокого сприйняття внутрішнього світу іншої людини, що включає його осмислення й оцінку так, як уявляє собі і переживає це об'єкт емпатії, проте, додамо, що надалі «включаються» співчуття та співпереживання іншій людині як емоційний і поведінковий відгук на її почування.

Одне 3 перших визначень емпатії належить 3. Фрейду, який розумів ії як врахування психотерапевтом психічного стану пацієнта, вміння поставити себе у цей стан і намагання зрозуміти його, порівнюючи зі своїм [5, с. 38].

Сучасне розуміння емпатії в психотерапії коротко, але досить змістовно сформулював Дж. Іган: «емпатія - це здатність розуміти та проникати у світ іншої людини, а також передати їй це розуміння» [4], - проте й досі не втрачає свого значення грунтовний аналіз ролі емпатії у клієнт-центрованій психотерапії К. Роджерса. Згідно К. Роджерса, «бути в стані емпатії означає сприймати внутрішній світ іншої людини точно, зі збереженням емоційних і смислових відтінків. Як нібито стаєш цим іншим, але без втрати відчуття «як нібито». Так, відчуваєш радість чи біль іншої людини, як вона їх відчуває, і сприймаєш їх причини, як вона їх сприймає... Емпатійний психотерапевт проникливо уловлює смисл стану, який переживає пацієнт у даний конкретний момент, і вказує на цей сенс, щоб допомогти пацієнту сконцентруватися на ньому і спонукати пацієнта до подальшого і більш повного безперешкодного переживання» [15]. К. Роджерс також підкреслює необхідність 
повідомлення клієнту про свої враження, щоб перевірити їх адекватність стану і переживанням людини та допомогти їх пережити «більш повно і конструктивно» (крім того, К. Роджерс вважав, що коли хтось розуміє, як почуває чи розуміє інший, без бажання аналізувати чи засуджувати його, це дозволяе рости), та зазначає трудність бути емпатійним: «це означає бути відповідальним, активним, сильним, $\mathrm{i}$ в той же час, - тонким і чутливим»; неупередженість сприйняття внутрішнього світу іншої людини; на деякий час втрату себе у цьому світі [15].

Отже, важливою складовою процесу емпатії у психотерапії вважається повідомити клієнту, що його переживання ситуації розуміють, тоді як дехто з дослідників «вважає недоцільним ... включати реакцію об'єкта емпатії в сам акт емпатії» [2, с. 33]. Ми ж схильні розглядати третю позицію (можливо, не в контексті психотерапії): не завжди доречно повідомляти об'єкту емпатії всю повноту нашого розуміння його переживань і глибину співчуття чи співпереживання йому: у певних випадках деякі особи не бажають, щоб їхні переживання бодай хтось помітив, і тим більше, зрозумів чи виявив співчуття. Тому, перш, ніж повідомляти людині про «своє розуміння» іiі стану, переживань і ситуації, варто спробувати передбачити реакцію на це «об'єкта» емпатiï.

3 погляду зарубіжної психології, емпатія вивчається у контексті допомагаючої і аль- труїстичної поведінки. Зокрема, Д.Бетсон вважає, що «чистий» альтруїзм (на відміну від допомоги іншій людині через егоїстичну причину (щоб отримати вигоду для себе), наприклад, щоб позбутися незручності від вигляду людини, яка страждає, і зберегти власний спокій; чи заслужити соціальну винагороду) людина проявляє тоді, коли відчуває емпатію по відношенню до того, хто потребує допомоги [1, с. 367]. I емпатія (empathy) - це здатність поставити себе на місце іншої людини, побачити i відчути події, що відбуваються (наприклад, зрадіти чи засмутитися) так, як бачить і почуває ця людина. Тобто саме емпатія є тим фактором, що спонукає людину проявляти альтруїстичну поведінку, і чим більше особі властиво співпереживати іншій людині, тим більше вона готова допомагати в конкретному випадку. Хоча насправді, як зізнається вчений, важко виявити справжню мотивацію зовні альтруїстичної допомагаючої поведінки [1].

Найбільш цікавими для нас виявилися результати сучасного дослідження емпатії зарубіжними вченими: на основі знання про те, що «співчуття іншій людині, яка відчуває біль, активує в мозку ті ж області, які відповідають за почуття нашого власного болю» [21], М.Ратджен та інші перевіряли припущення про те, що уявлення про чужий біль, що виникає через наші переживання («абстрактне» його відчуття), забезпечують ті самі нейронні контури, які відповідають за 
«справжні» (власні) больові відчуття людини. Зазначимо, що, на думку багатьох дослідників, до різновидів абстрактного болю відноситься емпатія - здатність співпереживати стражданням іншої людини. У цьому науковців переконували і результати МРТ, які свідчили: чим сильніше людина співчуває іншій людині, чий біль вона спостерігає, тим сильніше в мозку активуються ті його частки, які починають активно працювати під впливом власного болю.

За результатами експерименту М.Ратджена й ін. [21] виявилося, що зменшення чутливості до болю (причому не справжнє, а 3 допомогою плацебо) ослаблює емпатію людини і знижує іï сприйнятливість до страждань чужих людей. А звідси був зроблений висновок, що здатність людини до емпатії прямо пов'язана з їі чутливістю до болю: нейронні контури головного мозку, залучені до формування відчуття болю та почуття співчуття до іншої людини, яка відчуває біль, не ідентичні, але в значній мірі перекриваються [21].

Отже, емпатія (грець. empatheia «почування всередину», співчуття) - це усвідомлене розуміння внутрішнього світу чи емоційного стану іншої людини, відмітною особливістю якого $є$ те, що ця властивість стосується широкого спектру емоцій: як позитивного, так і негативного відтінку [20].

За Е. М. Балашовим, емпатія - це глибоке і безпомилкове сприйняття внутрішньо- го світу іншої людини, іiі прихованих емоцій i смислових відтінків, емоційне співзвуччя з іiі переживаннями, використання всієї глибини розуміння цієї людини не у своїх, а в іiї інтере$\operatorname{cax}[2$, c. 31$]$.

Російські вчені Т. I. Пашукова та Є. А. Троїцька зазначають, що «в психології до емпатії відносять цілий ряд психічних явищ, таких, як співчуття, співпереживання, «входження» в стан іншої людини, «проникнення» у світ переживань людей, розуміння людиною емоцій і почуттів інших людей, здатність уявити себе на місці іншого i навіть рефлексію розуміння емоційних станів і переживань іншої людини» [12, с.197]. Зазначимо, що з емпатією у психології пов'язуються не лише вище перелічене, але й симпатія, інтуїція, просоціальна, альтруїстична i допомагаюча поведінка, що, з нашого погляду, є свідченням як комплексного і складного характеру цього психічного феномену, так i відсутності систематизованого, узагальненого і цілісного уявлення про емпатію. Розуміючи емпатію як процес переважно емоційний, T. I. Пашукова визначає іiї як «особливого роду емоцію, змістом якої є відображене суб'єктом емпатії ставлення людини, яка переживає, до об'єктивної дійсності, виражене в тих самих почуттях і виявлене зовні у формах експресії, схожих на експресії людини, яка переживає» [12, с. 197].

Зазначимо, що ми не готові визнати емпатію суто емоційним процесом, оскільки 
вбачаємо у ній окрім емоційного не лише когнітивний і поведінковий компоненти: на усвідомленому рівні емпатія - це і «осягнення» внутрішнього стану іншої людини, і відповідна ситуації підтримуюча і допомагаюча поведінка суб'єкта емпатії; на не цілком усвідомленому рівні (про що, зокрема, свідчить неможливість контролювати цей процес) емпатія (як синхронізація з чужими переживаннями та мимовільна втягнутість у внутрішній світ іншої людини) є результатом своєрідного позасенсорного інтуїтивного інсайту переживань іншої людини, зараження ними і тимчасової ідентифікації з об'єктом емпатії.

На думку I. М. Юсупова, емпатія являє собою феномен соціально-психологічного походження, що пов'язує свідому та несвідому інстанції психіки. Структура цього явища багаторівнева: прояви спостерігаються на психофізіологічному, психологічному та соціальнопсихологічному рівнях. Емпатія постає як процес, властивість і стан [20].

М. Хоффман диференціює такі стадії розвитку емпатійної реакції: емоційне зараження (реактивність дитини); егоцентричний емоційний дистрес (приводить до поведінки зі зменшення свого дискомфорту); справжній дистрес, коли поділяються переживання іншої людини (на його основі уже можлива поява альтруїстичних почуттів, спрямованих на іншого); стійка емпатія до іншої людини [6].

Ми поділяємо як позицію Г. БарреттаЛенарда щодо розуміння емпатії як комплекс- ного процесу, що складається з кількох циклів (етапів): вираження людиною, яка переживає, свого стану, сприйняття суб'єктом емпатії стану людини, яка переживає, реакція у відповідь від суб'єкта емпатії, сприйняття иієї реакиії об'єктом емпатії, зворотний зв'язок людини, яка переживає, на реакцію емпата), так і думку, що на кожному з них діють свої механізми [12, с. 204], проте, «обов'язковими» для процесу емпатії вважаємо лише окремі (виділені нами) етапи: стан людини - об'єкта емпатії - може зовні майже не виражатися, i на «зворотний зв'язок» очікувати не варто.

Варто також зазначити, що різні науковці схильні виділяти власні варіанти механізмів емпатії, по-своєму комбінуючи чи обираючи з такого переліку: зараження, ідентифікація, проекція та інтроекція, емоційне наслідування, розуміння емоцій інших людей, рефлексія, децентрація (розумова дія, завдяки якій людина здатна стати на позицію іншої людини) - афективна, інтелектуальна й соціальна [12]. Зокрема, Т. П. Гаврилова серед інших підкреслює важливу роль ідентифікації в емпатії, завдяки якій «виникає емоційний зв'язок між суб'єктом і об'єктом, який сприймається, що дозволяє цінності, норми іншого приймати як свої» [12, с. 202].

На думку I. М. Юсупова, функціональними механізмами емпатійного розуміння виступають емоційно-когнітивна децентрація суб'єкта і його ідентифікація з об'єктом емпатії, причому результатом цього розуміння $\epsilon$ 
суб'єктивна упевненість в адекватності відтворених паттернів і внутрішньої сутності об'єкта, що пізнається [20].

Як на нас, людина може стати на позицію іншої людини і поглянути на світ і її проблему її поглядом і не звертаючись до раціонального ï осмислення, а, наприклад, через симпатію чи довіру до цієї людини (психологічну чи емоційну близькість), навіть не встигнувши зрозуміти, чому вона це робить. Бути емпатійною людиною не означає прораховувати й оцінювати раціонально чи емоційно позицію і переживання іншої людини перш, ніж поглянути на ситуацію ії очима, з її внутрішньої позиції. Усе це приводить нас до думки, що саме зараження й ідентифікація $\epsilon$ найбільш очевидними механізмами емпатії. Так, С. Престон і Ф. де Вааль вважають, що «сприйняття емоційних станів інших людей автоматично активує схожі переживання у самій людині» [16, с. 56].

Особливими формами емпатії є співпереживання та співчуття. Співпереживання це переживання суб'єктом тих самих емоційних станів, які відчуває інша людина, через ототожнення $з$ нею. Співчуття - переживання власних емоційних станів 3 приводу почуттів іншої людини. Воно спонукає допомогти іншій людині, через що його вважають «гуманістичною» емпатією, на відміну від співпереживання (переживання за себе) - егоцентричної емпатії [18].

I. I. Штих форму емпатії, спрямовану людиною на себе («егоїстичну»), також позначає поняттям «співпереживання», стан дискомфорту чи дистресу. Така емпатія виникає, на думку науковця, коли сприйняття стану партнера зі спілкування викликає напругу та фрустрацію міжособистісних потреб суб'єкта емпатії (чи, додамо, його неприємні спогади), роблячи його емоційно вразливим [17].

На наш погляд, якщо людина «включається» у переживання іншої людини, ставши на iï точку зору та почавши усвідомлювати, що такі почуття 3 аналогічного чи схожого приводу мають до неї пряме відношення, - вона не просто егоїстично спрямовує емпатійні переживання на себе, себе вона починає жаліти (емпатія в цьому випадку переживається не як «співпереживання» (яке, за тлумачним словником, означає «поділяти переживання іншої людини», що не зовсім відповідає випадку емпатії до себе), а як власне жалість; собі ми не співпереживаємо: ми або просто із сумом згадуємо неприємні колишні почуття, знову переживаючи їх, або жаліємо (шкодуємо) себе).

Іноді вчені виділяють два види емпатії, залежно від того, на які емоції (позитивні чи негативні) вона спрямована, підкреслюючи початкову нейтральність даного феномена i зазначаючи, що негативна емпатія значно більше поширена, диференційована та стосується більшого кола міжособистісних стосунків, порівняно 3 позитивною емпатією («співрадінням») [16, с. 56]. 
Є. А. Троїцька, проаналізувавши погляди на емпатію зарубіжних науковців, дійшла висновку, що «вчені, які розглядають емпатію як когнітивний феномен, вказують на те, що вона являє собою пізнавальну здібність», ті ж, хто відстоює погляд на емпатію як на емоційне явище, «говорять про неї як про емоційний стан, емоційну відповідь на переживання інших людей» $[16$, с. 60].

I. М. Юсупов же стверджує, що емоційно-когнітивні компоненти емпатійного розуміння знаходяться між собою у відношеннях комплементарності, взаємодіючи при дефіциті інформації про об'єкт емпатії; що може відбуватися на підсвідомому (при емоційному зараженні) чи свідомому (у випадку рефлексивного судження й атрибуції) рівнях [20].

Тоді як більшість вчених, узагальнюючи інформацію щодо різних визначень емпатії у вітчизняній і зарубіжній психології, приходять до виділення у структурі емпатії трьох основних компонентів:

емоційного - здатність розпізнавати та розуміти емоційні стани іншої людини, що характеризується як пасивне співчуття, форма співучасті в емоційному стані партнера зі спілкування;

когнітивного - здатність подумки переноситися у думки, почуття та дії іншої людини; сприймати та розуміти внутрішній світ іншої людини, співчувати їй;

поведінкового - як здатність допомагати іншій людині, полегшуючи їі страждання
$[17$, c. 178$]$.

В. В. Бойко у структурі емпатії виділяє: раціональний канал, що характеризує спрямованість уваги, сприйняття і мислення емпатійної людини на іншу людину - іiї стан, проблеми, поведінку; проявляється як прояв спонтанного інтересу до іншої людини, який відкриває «шлюзи» емоційного й інтуїтивного іiі відображення; емоційний канал емпатії, що визначає здатність людини входити до емоційного резонансу з оточуючими: співпереживати, проявляти співучасть; емоційна чутливість у цьому разі стає засобом «входження», «підстроювання» до енергетичного поля партнера; інтуїтивний канал емпатії, як здатність людини помічати поведінку партнерів, діяти в умовах дефіциту вихідної інформації про них, спираючись на досвід підсвідомості; на рівні інтуїції замикаються й узагальнюються різні дані про партнерів [11].

Р.Бернс наводить такі потенційні характеристики людини, здатної до емпатії: а) прояв терпимості до вираження емоцій з боку іншої людини; б) уміння глибоко проникнути у світ іншої людини, не розкриваючи при цьому свого власного; в) готовність адаптувати своє сприйняття до сприйняття іншої людини, щоб досягти більшого розуміння того, що з нею відбувається [8], - тоді як Ю. Зубцов зосереджується на «темній стороні емпатії»: від емпатів завжди очікують підтримки та поради, i саме це спричинює різноманітні проблеми та незручності для самих емпатійних особистос- 
тей. Серед них, зокрема, такі: нездатність керувати власними емоціями; перевтома від постійних зіткнень 3 негативними емоціями та негативною енергією інших; їх використовують через доброту і довірливість ті, хто вміє лише «брати»; вони нехтують собою, ін. [3].

Проте, цілком очевидно, як зазначає С. С. Степанов, що емпатія $\epsilon$ цінною професійною якістю психолога, чия практична діяльність пов'язана з безпосередніми контактами з людьми, з допомогою у вирішенні їх проблем. При цьому особливо важливо не забувати про її суб'єктивні межі, вихід за які може завершитися професійним вигоранням. Тобто психолог повинен уміти проникнутися переживаннями іншої людини, однак не настільки, щоб перетворити чужі проблеми на свої [19].

Проведене нами дослідження відповідно до мети роботи, вибіркою в якому стали студенти III-IV кусів - майбутні психологи ( $\mathrm{n}=40)$ (використовувалися методики: для визначення рівня суб'єктивного контролю (тест РСК) Дж. Роттера, адаптація Є. Ф. Важина, С. А. Голинкіної, А. М. Еткінда; діагностики рівня емпатійних здібностей В. В. Бойко; «Шкала емоційного відгуку», методика діагностики емпатії за А. Меграбіаном i Н. Эпштейном; шкала явної тривожності (Manifest Anxiety Scale - MAS) Дж. Тейлор, адаптація Т. А. Нємчина), дозволило виявити:

опитаним властивий в основному інтернальний локус контролю, який проявляється ситуативно (у 67,5 \% вибірки) або переважно (у 32,5\%); серед різних життєвих сфер, інтернальність досліджувані проявлять частіше у виробничих (навчальних) відносинах (середня - 68,5 \% від максимального значення показника), ніж у міжособистісних (42 \% відповідно), та приблизно на одному рівні у сферах досягнень, невдач та сімейних стосунків (57,1 \%, 57,5 \% та 53,5 \% відповідно);

майже всі студенти виявилися дуже тривожними, про що свідчать високі та дуже високі рівні показника - у 72,5 \% і 15 \% вибірки відповідно;

за методикою В. В. Бойка, у більшості опитаних виявлено знижений (у 42,5 \%) та низький (у 32,5 \%) рівні прояву емпатійних здібностей (у решти вибірки - середній), тоді як, за методикою А. Меграбіана, домінуючим у вибірці є високий рівень «емпатійного відгуку» (у 70 \% студентів), що доповнюється дуже високим (у 20 \%) та нормальним (у $10 \%$ опитаних). Очевидно, автори методик дещо порізному розуміють поняття «емпатія». Саме про це, на наш погляд, свідчать результати кореляції: між даними методиками іï показник $-\mathrm{r}=0,51$, тоді як показник найсильнішої кореляції методики А. Меграбіана - 3 емоційним каналом емпатії (за методикою В. В. Бойка) $\mathrm{r}=0,75$; зазначимо, що А. Меграбіан емпатію розуміє як власне емоційну реакцію;

серед емпатійних тенденцій, за середніми показниками, у досліджуваних краще за інші розвинутий емоційний канал в емпатії, середня - 3,23 балів, тобто опитані схильні до 
прояву співпереживання та співучасті оточуючим, здатні зрозуміти їх внутрішній світ і поведінку, емоційно налаштуватися на них; дещо менші прояви ідентифікації (3 бали) та раціонального каналу в емпатії (2,955 балів), що свідчить про те, що досліджувані досить уважні до партнерів зі спілкування, вміють їх зрозуміти, поставити себе на місце партнера; інші показники емпатії, особливо іiі інтуїтивний канал, у вибірці виявляються значно слабше; кореляційний аналіз, проведений за результатами дослідження, пов'язує рівень емпатії досліджуваних з тривожністю особистості й інтернальним локусом контролю: так, тривожність корелює 3 розвитком інтуїтивного каналу $(\mathrm{r}=0,33)$, установкою та ідентифікацією в емпатії ( $r=0,39$ та $r=0,54$ відповідно), a також із загальним показником емпатії опитаних за методикою В.В. Бойка $(\mathrm{r}=0,46)$; інтернальний РСК - $з$ раціональним каналом емпатії $(\mathrm{r}=0,34)$; інтернальність у досягненнях -3 емоційним каналом $(\mathrm{r}=0,38)$, у невдачах -3 раціональним каналом та ідентифікацією в емпатії $(r=0,39$ та $r=-0,37)$; інтернальність у виробничих відносинах -3 установкою $(\mathrm{r}=$ $0,34)$ та проникаючою здатністю в емпатії $(\mathrm{r}=$ $0,44)$, у сімейних стосунках - 3 розвитком емоційного каналу емпатії $(\mathrm{r}=0,38)$ та показником емпатії за А. Меграбіаном $(\mathrm{r}=0,34)$.

Висновки. Отже, емпатію в психології вважають соціальною емоцією, особистісною рисою, властивістю чи здібністю людини; розуміють ії як процес чи стан. За схожістю пї порівнюють із симпатією, інтуїцією, психологічним тактом, рефлексією, ідентифікацією, ін.

Під емпатією (як складним психологічним феноменом) найчастіше розуміють:

процес розуміння психічного стану іншої людини;

вміння поставити себе на їі місце і відчути все (думки, почуття, сенси, ін.), як відчуває ця людина;

переживання цього стану разом 3 нею так, ніби вона сама все відчуває;

співчуття до іншої людини з приводу їі страждання, що трансформується у бажання їй допомогти;

у психотерапії додається ще одна ознака емпатії: повідомлення людині, яка переживає негативні події чи життєві ситуації, повноти «входження» психотерапевта у іiі емоційний стан, що клієнта насправді чують і розуміють.

Емпатійність майбутніх психологів розвинута недостатньо, за виключенням суто емоційної іiі складової, і пов'язується 3 тривожністю та інтернальністю особистості.

\section{Перспективу подалыших розвідок 3} досліджуваної проблеми вбачаємо у порівняльному аналізі розвитку емпатії у представників різних груп професій та їі зв'язку з іншими емоціями.

Перелік використаних джерел:

1. Аронсон Э. Социальная психология. Психологические законы поведения человека в социуме / 
Э.Аронсон, Т.Уилсон, Р.Эйкерт. - СПб.: ПРАЙМЕВРОЗНАК, 2002. - 560 с. - (Серия «Психологическая энциклопедия»).

2. Балашов Е. М. Психологічні особливості соціальної емпатії студентів як засобу самореалізації / Е.M. Балашов // Наукові записки Національного університету «Острозька академія». - Серія «Психологія i педагогіка». - 2014. - Вип. 28. - С.28-39.

3.Зубцов Ю. Тёмная сторона эмпатии [Электронный pecypc] / Ю.Зубцов. - Режим доступа: http:// www.psychologies.ru/self-knowledge/behavior/temnayastorona-empatii/.

4. Иган Дж. Базисная эмпатия как коммуникативный навык / Дж.Иган [Электронный ресурс] // Журнал практической психологии и психоанализа. - 2001. - № 1. Режим доступа : http://www.psyjournal.ru.

5. Ильин Е. П. Психология помощи. Альтруизм, эгоизм, эмпатия / Е.П. Ильин. - СПб.: Питер, 2013. - 304 с. (Серия «Мастера психологии»).

6. Карягина T. Д. Эволюция понятия «эмпатия» в психологии: дис. ... канд. психол. наук : 19.00.01 [Электронный ресурс] / Татьяна Дмитриевна Карягина. - М.: МГППУ, 2013. - 175 с. - Режим доступа: http:// www.dissercat.com/content/evolyutsiya-ponyatiyaempatiya-v-psikhologii.

7. Кузьмина В. П. Теоретический аспект исследования эмпатии как актуальная проблема современной психологии [Электронный ресурс] / В.П. Кузьмина // Вестник ВятГУ. - 2007. - № 17. - Режим доступа: URL: https:// cyberleninka.ru/article/n/teoreticheskiy-aspektissledovaniya-empatii-kak-aktualnaya-problemasovremennoy-psihologii.

8. Лазоренко T. Н. Роль эмпатии в профессиональной деятельности психологов [Электронный ресурс] / Т.Н. Лазоренко, А.M. Ананьев // Journal of Psychology. - Special Pedagogy. Social Work (PSPSW). - Vol. 46. - Iss. 1. 2017. - Режим доступа: http://psihologie.upsc.md.

9. Макаревич H. Человечество вымрет от недостатка эмпатии [Электронный ресурс] / Ника Макаревич. Режим д доступа: https:/www.jv.ru/news/ psikhologhiia/15823-chelovechestvo-vimret-ot-nedostatkaempatii.html.

10. Матюх T. M. Емпатія як трансестетичний феномен : автореф. дис. на здобуття наук. ступеня канд. філос. наук : спец. 09.00.08 - «Естетика» / Т.М. Матюх. - К., 2016. -23 c.

11. Методика диагностики уровня эмпатических способностей В. В. Бойко (тест на эмпатию Бойко) [Электронный ресурс]. - Режим доступа : http:// psycabi.net/testy/229-metodika-diagnostiki-urovnyaempaticheskikh-sposobnostej-v-v-bojko-test-na-empatiyubojko.

12. Пашукова Т. И. Механизмы и функции эмпатии / Т.И. Пашукова, Е.А. Троицкая [Электронный ресурс] // Вестник МГЛУ. - 2010. - № 586. - Режим доступа: URL: https://cyberleninka.ru/article/n/mehanizmy-i-funktsii -empatii.

13. Понятие «эмпатия» в трудах психологов [Электронный ресурс]. - Режим доступа: http:// studbooks.net/1299021/psihologiya/ ponyatie_empatiya_trudah_psihologov.

14. Пузыревский В. Ю. Феномен эмпатии в контексте современной западной философии [Электронный ресурс] / В.Ю. Пузыревский // Альманах «Сибирь». Философия. Образование. - 2002. - Вып. 6). - С.103118. - Режим доступа: http://hpsy.ru/public/x2655.htm.

15. Роджерс K. Эмпатия // Психология мотивации и эмоций / Под ред. Ю. Б. Гиппенрейтер, М. В. Фаликман. - М.: ЧеРо, 2002. - С. 428-430.

16. Троицкая E. A. Концепция эмпатии в зарубежной психологии конца XX - начала XXI века [Электронный peсурс] / Е.А. Троицкая // Вестник МГЛУ. - 2011. - № 613. - С.52-64. - Режим доступу: URL: https:// cyberleninka.ru/article/n/kontseptsiya-empatii-vzarubezhnoy-psihologii-kontsa-xx-nachala-xxi-veka.

17. Штих I. I. Здатність до емпатії як компонент професійних здібностей психолога / I.I. Штих // Науковий вісник Мукачівського державного університету. - Серія «Педагогіка та психологія» . - 2015. - Випуск 2 (2). C.177-180. 
18. Эмпатия // Большой психологический словарь / Под ред. Б.Г. Мещерякова, акад. В.П. Зинченко. - М.: Прайм-ЕВРОЗНАК, 2003. - С.563-564.

19. Эмпатия // Степанов С.С. Популярная психологическая энциклопедия / С.С. Степанов. - М.: Эксмо, 2005. - C.661-664.

20. Юсупов И. М. Психология эмпатии: дис. ... доктора психол. наук: 19.00.01 [Электронный ресурс] / Ильдар Масгудович Юсупов. - СПб., 1995. - 252 с. - Режим доступа: http://www.dissercat.com/content/psikhologiyaempatii\#ixzz5BiTQO5WV.

21. Rütgen $M$. Placebo analgesia and its opioidergic regulation suggest that empathy for pain is grounded in self pain [Електронний ресурс] / M. Rütgen, E.-M. Seidel, G. Silani [and others] // PNAS. - September 28. - 2015. - Режим доступу: https://doi.org/10.1073/pnas.1511269112.

\section{References (Transliteration):}

1. Aronson Je. Social'naja psihologija. Psihologicheskie zakony povedenija cheloveka $\mathrm{v}$ sociume / Je.Aronson, T.Uilson, R.Jejkert. - SPb.: PRAJM-EVROZNAK, 2002. 560 s. - (Serija «Psihologicheskaja jenciklopedija»).

2. Balashov E. M. Psyhologichni osoblyvosti social'noi' empatii' studentiv jak zasobu samorealizacii' / E.M. Balashov // Naukovi zapysky Nacional'nogo universytetu «Ostroz'ka akademija». - Serija «Psyhologija i pedagogika». - 2014. - Vyp. 28. - S.28-39.

3. Zubcov Ju. Tjomnaja storona jempatii [Jelektronnyj resurs] / Ju.Zubcov. - Rezhim dostupa: http:// www.psychologies.ru/self-knowledge/behavior/temnayastorona-empatii/.

4. Igan Dzh. Bazisnaja jempatija kak kommunikativnyj navyk / Dzh.Igan [Jelektronnyj resurs] // Zhurnal prakticheskoj psihologii i psihoanaliza. - 2001. - № 1. Rezhim dostupa : http://www.psyjournal.ru.

5. Il'in E. P. Psihologija pomoshhi. Al'truizm, jegoizm, jempatija / E.P. Il'in. - SPb.: Piter, 2013. - 304 s. - (Serija «Mastera psihologii»).

6. Karjagina T. D. Jevoljucija ponjatija «jempatija» v psihologii: dis. ... kand. psihol. nauk : 19.00.01 [Jelektronnyj resurs] / Tat'jana Dmitrievna Karjagina. - M.: MGPPU, 2013. - 175 s. - Rezhim dostupa: http:// www.dissercat.com/content/evolyutsiya-ponyatiyaempatiya-v-psikhologii.

7. Kuz'mina $V$. P. Teoreticheskij aspekt issledovanija jempatii kak aktual'naja problema sovremennoj psihologii [Jelektronnyj resurs] / V.P. Kuz'mina // Vestnik VjatGU. 2007. - № 17. - Rezhim dostupa: URL: https:// cyberleninka.ru/article/n/teoreticheskiy-aspektissledovaniya-empatii-kak-aktualnaya-problemasovremennoy-psihologii.

8. Lazorenko T. N. Rol' jempatii v professional'noj dejatel'nosti psihologov [Jelektronnyj resurs] / T.N. Lazorenko, A.M. Anan'ev // Journal of Psychology. - Special Pedagogy. Social Work (PSPSW). - Vol. 46. - Iss. 1. 2017. - Rezhim dostupa: http://psihologie.upsc.md.

9. Makarevich N. Chelovechestvo vymret ot nedostatka jempatii [Jelektronnyj resurs] / Nika Makarevich. - Rezhim dostupa: https://www.jv.ru/news/psikhologhiia/15823chelovechestvo-vimret-ot-nedostatka-empatii.html.

10. Matjuh T. M. Empatija jak transestetychnyj fenomen : avtoref. dys. na zdobuttja nauk. stupenja kand. filos. nauk : spec. 09.00.08 - «Estetyka» / T.M. Matjuh. - K., 2016. $23 \mathrm{~s}$.

11. Metodika diagnostiki urovnja jempaticheskih sposobnostej V. V. Bojko (test na jempatiju Bojko) [Jelektronnyj resurs]. - Rezhim dostupa : http://psycabi.net/ testy/229-metodika-diagnostiki-urovnya-empaticheskikhsposobnostej-v-v-bojko-test-na-empatiyu-bojko.

12. Pashukova T. I. Mehanizmy i funkcii jempatii / T.I. Pashukova, E.A. Troickaja [Jelektronnyj resurs] // Vestnik MGLU. - 2010. - № 586. - Rezhim dostupa: URL: https:// cyberleninka.ru/article/n/mehanizmy-i-funktsii-empatii.

13. Ponjatie «jempatija» v trudah psihologov [Jelektronnyj resurs]. - Rezhim dostupa: http://studbooks.net/1299021/ psihologiya/ponyatie_empatiya_trudah_psihologov.

14. Puzyrevskij V. Ju. Fenomen jempatii v kontekste sovremennoj zapadnoj filosofii [Jelektronnyj resurs] / V.Ju. Puzyrevskij // Al'manah «Sibir'». - Filosofija. 
Obrazovanie. - 2002. - Vyp. 6). - S.103-118. - Rezhim dostupa: http://hpsy.ru/public/x2655.htm.

15. Rodzhers K. Jempatija // Psihologija motivacii i jemocij / Pod red. Ju. B. Gippenrejter, M. V. Falikman. M.: CheRo, 2002. - S. 428-430.

16. Troickaja E. A. Koncepcija jempatii v zarubezhnoj psihologii konca XX - nachala XXI veka [Jelektronnyj resurs] / E.A. Troickaja // Vestnik MGLU. - 2011. - № 613. - S.52-64. - Rezhim dostupu: URL: https:// cyberleninka.ru/article/n/kontseptsiya-empatii-vzarubezhnoy-psihologii-kontsa-xx-nachala-xxi-veka.

17. Shtyh I. I. Zdatnist' do empatii' jak komponent profesijnyh zdibnostej psyhologa / I.I. Shtyh // Naukovyj visnyk Mukachivs'kogo derzhavnogo universytetu. - Serija «Pedagogika ta psyhologija» . - 2015. - Vypusk 2 (2). S.177-180.

18. Jempatija // Bol'shoj psihologicheskij slovar' / Pod red. B.G. Meshherjakova, akad. V.P. Zinchenko. - M.: PrajmEVROZNAK, 2003. - S.563-564.

19. Jempatija // Stepanov S.S. Populjarnaja psihologicheskaja jenciklopedija / S.S. Stepanov. - M.: Jeksmo, 2005. - S.661-664.

20. Jusupov I. M. Psihologija jempatii: dis. .. doktora psihol. nauk: 19.00.01 [Jelektronnyj resurs] / Il'dar Masgudovich Jusupov. - SPb., 1995. - 252 s. - Rezhim dostupa: http://www.dissercat.com/content/psikhologiyaempatii\#ixzz5BiTQO5WV.

21. Rütgen M. Placebo analgesia and its opioidergic regulation suggest that empathy for pain is grounded in self pain [Електронний ресурс] / M. Rütgen, E.-M. Seidel, G. Silani [and others] // PNAS. - September 28. - 2015. - Режим доступу: https://doi.org/10.1073/pnas.1511269112.

\section{Chaplak Yan}

Ph. D (psychological sciences), associate professor of Psychology Department, Yuriy Fedkovych Chernivtsi National University, Chernivtsi (Ukraine)

\section{THE PROBLEM OF EMPATHY IN PSYCHOLOGY AND ITS IMPORTANCE IN THE PROFESSIONAL DEVELOPMENT OF A PSYCHOLOGIST}

\section{ABSTRACT}

Article is deals with the analysis of the phenomenon of empathy as a complex comprehensive psychic phenomenon, the essence of which - in the condolence and compassion to another person on the basis of perception of her internal state, the ability to put oneself in the place of the suffering person, and look at the situation with her eyes, understand her thoughts and experiences.

It is noted that in psychology scientists are comprehensively studied the concept, types, forms and mechanisms of empathy, its structure and role in the formation of altruistic helping behavior and life activity of a person in general, but in the research of this phenomenon there is much uncertainty and controversy.

The purpose of this paper is to theoretically analyze various aspects of understanding of empathy in psychology and empirically investigate the level of empathy of future psychologists and its connection with their personal characteristics.

We note that we are not ready to recognize empathy as a purely emotional process, because we perceive in it, in addition to emotional, not only cognitive and behavioral components: at a conscious level, empathy is the "comprehension" of the internal state of another person, and appropriate to the situation support- 
ing and helping behavior of the subject of empathy; on an unconscious level (about which, in particular, testifies to the inability to control this process) empathy (as synchronization with someone else's experiences and involuntary involvement in the inner world of another person) is the result of a peculiar of non-sensory intuitive insight of the experiences of another person, transmission by them and temporary identification with the object of empathy.

The following techniques: to determine the level of subjective control (LSC test) by J. Rotter, adaptation of E. F. Vazhin, S. A. Golynkina, A. M. Aktind; diagnostics of the level of empathic abilities V.V. Boyko; "Scale of emotional response", technique of diagnostics of empathy by A.Megrabian and N. Epshtein; Manifest Anxiety Scale (MAS) J. Taylor, adaptation of T.A. Nemchin), - were used in the empirical study

The results of the empirical study indicate that, despite the fact that empathy is a professionally important quality of a psychologist, its development in students - future psychologists is inadequate (mostly low and lower). The exception is the emotional component of empathy, which in most of the respondents is manifested at a high level, correlated with anxiety and the internal level of subjective control of personality.

It is concluded that empathy (as a complex psychological phenomenon) is often understood as: the process of understanding of the mental state of another person; the ability to put oneself in its place and feel everything (thoughts, feelings, meanings, etc.), how this person feels; condolence for another person for her suffering, which transforms into a desire to help her; in psychotherapy, another feature of empathy is added: a message to a person who is experiencing negative events or life situations, the completeness of the "entry" of the therapist into her emotional state, that the client is actually heard and understood.

Key words: empathy, condolence, compassion, mechanisms of empathy, anxiety, internality.

\section{Чаплак Ян Васильевич}

Кандидат психологических наук, дочент кафедры психологии Черновицкого национального университета имени Юрия Федьковича, г. Черновиь (Украина)

\section{ПРОБЛЕМА ЭМПАТИИ В ПСИХОЛОГИИ И ЕЕ ВАЖНОСТЬ В ПРОФЕССИОНАЛЬНОМ СТАНОВЛЕНИИ ПСИХОЛОГА}

Аннотация. Статья связана с анализом феномена эмпатии как сложного комплексного психического явления, суть которого - в сочувствии и сопереживании другому человеку на основе восприятия его внутреннего состояния, умении поставить себя на место человека, который страдает, и взглянуть на ситуацию его глазами, понять его мысли и переживания.

Отмечено, что в психологии учеными разносторонне изучены понятие, виды, формы 
и механизмы эмпатии, определена ее структура и роль в формировании альтруистического, помогающего поведения и жизнедеятельности человека в целом, однако в исследовании этого феномена до сих пор много неясного и спорного.

Цель этой работы - теоретически проанализировать различные аспекты понимания эмпатии в психологии и эмпирически исследовать уровень эмпатийности будущих психологов и его связь с их личностными характеристиками.

Указано, что мы не готовы признать эмпатию чисто эмоциональным процессом, поскольку видим в ней кроме эмоционального не только когнитивный и поведенческий компоненты: на осознанном уровне эмпатия - это и «постижения» внутреннего состояния другого человека, и соответствующее ситуации поддерживающее и помогающее поведение субъекта эмпатии; на не вполне осознанном уровне (о чем, в частности, свидетельствует невозможность контролировать этот процесс) эмпатия (как синхронизация с чужими переживаниями и невольная вовлеченность во внутренний мир другого человека) является результатом своеобразного внесенсорного интуитивного инсайта переживаний другого человека, заражение ими и временной идентификации с объектом эмпатии.

В эмпирическом исследовании использовались следующие методики: для определения уровня субъективного контроля (тест
РСК) Дж. Роттера, адаптация Е.Ф. Важина, С. А. Голинкиной, А. М. Эткинда; диагностики уровня эмпатических способностей В.В. Бойко; «Шкала эмоционального отклика», методика диагностики эмпатии по А. Меграбиану и Н.Эпштейну; шкала явной тревожности (Manifest Anxiety Scale - MAS) Дж. Тейлор, адаптация Т.А. Немчина)

Результаты эмпирического исследования показывают, что, несмотря на то, что эмпатия является профессионально ценным качеством психолога, ее развитие у студентов будущих психологов недостаточно (преимущественно пониженного и низкого уровня). Исключением является эмоциональная составляющая эмпатии, которая у большинства исследуемых проявляется на высоком уровне, корреляционно связываясь с тревожностью и интернальным уровнем субъективного контроля личности.

Сделан вывод о том, что эмпатию (как сложный психологический феномен) чаще всего истолковывают как: процесс понимания психического состояния другого человека; умение поставить себя на его место и ощутить все (мысли, чувства, смыслы, др.), как чувствует этот человек; переживания этого состояния вместе с ним так, будто он сам все чувствует; сочувствие к другому человеку по поводу его страдания, которое трансформируется в желание ему помочь; в психотерапии добавляется еще один признак эмпатии: сообщение человеку, который переживает негатив- 
ные события или жизненные ситуации, полноты «вхождения» психотерапевта в его эмоциональное состояние, что клиента самом деле слышат и понимают.

Ключевые слова: эмпатия, сочувствие, сопереживание, механизмы эмпатии, тревожность, интернальность. 